\title{
TATA KELOLA WILAYAH SUMBER MATA AIR TIRTO ARUM, DESA SRIMULYO, KECAMATAN DAMPIT KABUPATEN MALANG
}

\author{
Sinollah \\ Universitas Islam Raden Rahmat Malang, sinollah@gmail.com
}

\begin{abstract}
Abstrak
Sumber air Tirto Arum merupakan satu-satunya sumber air yang tetap mengalir meskipun kemarau, khususnya di Desa Srimulyo, Dampit-Kabupaten Malang. Sumber air ini sudah dikelola dan didistribusikan kepada 196 KK. Pada tanggal 20 Pebruari 2019 pompa air mengalami kerusakan karena tertimbun longsor. Mesin pompa air berkekuatan 7,5 PK dengan kapasitas ketinggian 80 meter digunakan untuk mengaliri air dengan ketinggian 100 meter, sehingga penghubung antara dinamo dan kipas di dalam mesin terlepas. Secara kepemilikan, sumber air dan tandon masih menjadi milik pribadi. Tujuan dari kegiatan ini adalah melakukan pendampingan pengelolaan sumber air Tirto Arum dengan melibatkan peran serta pengelola, BPD dan masyarakat Desa Srimulyo. Pendekatan yang digunakan adalah kerjasama lintas program dengan pengelola, lintas sektor dengan aparat desa dan masyarakat dengan pendekatan Participatory Rural Appraisal (PRA). Hasil dari kegiatan ini adalah: 1). Berfungsinya kembali mesin pompa air dari sumber air Tirto Arum ke tandon yang selanjutnya didistribusikan ke warga; 2). tertatanya lingkungan sumber air Tirto Arum dengan cara dibersihkan longsoran dan membuat dinding penahan longsor dengan menggunakan karung yang diisi tanah dan pasir; 3). Sumber air Tirto Arum resmi menjadi milik Desa Srimulyo, begitu juga lahan yang ditempati tandon air dengan telah ditandatanganinya perjanjian hibah secara tertulis di atas materai antara pemilik sumber air dan pemilik tanah tempat tandon dengan Desa Srimulyo; 4). Ditanda tanganinya MoU antara Unira Malang dan Pemerintah Desa Srimulyo sebagai langkah awal untuk pelaksanaan Tridharma Perguruan Tinggi di Desa Srimulyo.
\end{abstract}

Kata Kunci: Pendampingan, Tatakelola, Sumber Mata Air Tirto Arum

\section{Abstract}

Tirto Arum water source is the only source of water that continues to flow despite dry season, especially in the Desa Srimulyo, Dampit-Malang Regency. This water source has been managed and has been distributed to 196 households. On February 20, 2019 the water pump was damaged due to a landslide. A 7.5 PK water pump engine with a capacity of 80 meters is used to flow water with a capacity of 100 meters, so that the connecting of connector between dynamo and fan inside the engine is released. By ownership, water sources and reservoirs are still private property. The purpose of this activity is providing assistance in managing Tirto Arum water source by involving the management, BPD and community in the Srimulyo Village. The approach used cross-program collaboration with managers, cross-sector collaboration with village officials and Participatory Rural Appraisal (PRA) approach. The results of this activity are: 1). The re-functioning of water pump machine; 2). the arrangement of Tirto Arum water source environment by cleaning landslides and making the retaining wall landslide using sacks filled with soil and sand; 3). The Tirto Arum water source officially belongs to Srimulyo Village, as well as the land occupied by water reservoir with the signing of a grant agreement in writing on the stamp between the owner with Srimulyo Village; 4). The signing of MoU between Unira Malang and Srimulyo Village Government as the initial step for implementation of the Higher Education Tridharma in Srimulyo Village.

Keywords: Mentoring, Governance, Tirto Arum water source 


\section{PENDAHULUAN}

Air adalah kebutuhan yang paling vital bagi makluk hidup. Tubuh manusia 90 persen terdiri dari air. Air tidak bisa lepas dari segala aktivitas manusia seperti makan, minum, mandi, listrik dan masih banyak lagi. Dalam laman Wikipedia, siklus air atau siklus hidrologi adalah siklus air yang tidak pernah berhenti dari atmosfer ke bumi dan kembali ke atmosfer melalui kondensasi, presipitasi, evaporasi dan transpirasi. Pemanasan air laut oleh sinar matahari merupakan kunci proses siklus hidrologi tersebut dapat berjalan secara terus menerus. Air berevaporasi, kemudian jatuh sebagai presipitasi dalam bentuk hujan, salju, hujan es dan salju, hujan gerimis atau kabut. Mata air adalah sebuah keadaan alami dimana air tanah mengalir keluar dari akuifer menuju permukaan tanah. Mata air merupakan bagian dari hidrosfer (Wikipedia, diakses 6 Maret 2019).

Desa Srimulyo merupakan salah satu desa yang terletak di Kecamatan Dampit Kabupaten Malang. Salah satu sumber mata air yang berada di Desa Srimulyo yaitu sumber mata air Tirto Arum yang masih baik dengan debit airnya yaitu 8 liter/detik. Sumber Mata Air Tirto Arum ini dikelola langsung oleh BPD (Badan Permusyawaratan Desa) yang digunakan untuk memenuhi kebutuhan air bersih bagi masyarakat Desa Srimulyo, selain itu juga dimanfaatkan oleh warga untuk irigasi dan MCK (Mandi, Cuci, Kakus). Mata Air Tirto Arum juga dimanfaatkan untuk memenuhi kebutuhan masyarakat luar Dusun Krajan yang nantinya akan dikelola oleh BUMDES (Badan Usaha Milik Desa).

Program pengabdian terkait dengan wilayah sumber mata air Tirto Arum mendapatkan respon dari masyarakat yang cukup baik. Pengelolaan sumber dalam hal kebersihan wilayah dan status wilayah sumber mata air yang masih belum jelas. Bangunan sumber mata air ini merupakan sebuah bangunan yang di biayai oleh pemerintah daerah sebesar 1,3 M. Tapi dalam pelaksanaan pembangunannya mengalami beberapa kendala, salah satunya bangunan yang tidak sesuai dengan yang telah di tentukan, akibatnya bangunan tersebut terbengkalai selama kurang lebih 2 tahun dan airpun tidak sampai mengalir ke warga sekitar.

Masalah lain yang timbul yaitu terjadinya tanah longsor pada wilayah sumber mata air yang mengakibatkan bak kontrol tertimbun tanah kurang lebih setinggi 1,5 meter dan sedalam 1 meter. Maka yang terjadi adalah banyaknya tanah yang masuk pada tandon utama yang mana bisa mengakibatkan kemacetan pada 
pompa air dan menjadikan kondisi air menjadi keruh.

Menurut Pak Kusairi selaku Ketua BPD (Badan Permusyawaratan Desa) Desa Srimulyo, Kecamatan Dampit Kabupaten Malang masalah ini tidak bisa dibiarkan berlarut-larut, maka pada tahun 2018 diadakan musyawarah dengan pihak Desa yang menghasilkan keputusan bahwasanya untuk pengelolaan sumber mata air sepenuhnya dikelola oleh BPD Desa Srimulyo, namun pada hasil musyawarah tersebut belum ada pernyataan tertulis dari Desa. Maka dari situ lah awal pendistribusian air ke masyarakat Desa Srimulyo, Dusun Krajan pada khususnya. Sumber mata air ini mengalir ke masyarakat belum genap 1 tahun, tetapi sudah melayani 186 KK yang meliputi wilayah Krajan dan sekitarnya.

Pada awal pelaksanaan pendistribusian air kepada warga mengalami beberapa kendala diantaranya yaitu: adanya masalah yang dihadapi oleh pengelola terkait dengan pendanaan maupun manajemen pengelolaan karena terbatasnya SDM yang ada di Desa Srimulyo. Menurut Pak Ponijo selaku sekretaris sekaligus tenaga lapangan dalam pengelolaan sumber air Tirto Arum, mengungkapkan bahwa pipa-pipa pada saluran air mengalami banyak kebocoran saat pertama kali pompa air dijalankan, karena dalam awal pemasangan pipa tersebut sangat tidak layak digunakan. Beliau mengungkapkan bahwa, pemborong proyek tersebut bukan pemborong yang ahli dalam bidang pengairan dan timbul prasangka. Ada indikasi dana proyek tersebut telah dikorupsi oleh pihak swasta maupun pemerintah.

Pada tanggal 20 Februari 2019 mesin pompa air mengalami kerusakan. Hal ini menyebabkan air tidak mengalir selama 2 hari 2 malam yang mengakibatkan banyak keresahan yang timbul di masyarakat. Kerusakan pada pompa air disebabkan karena mesin pompa air bekerja melampaui limit kapasitas kerja yang sebenarnya. Akibatnya mesin tidak bekerja dan air tidak dapat mengalir ke tandon ke-tiga yang selanjutnya akan di distribusikan kepada masyarakat.

Hipotesis masyarakat mengenai terhambatnya air yang terdistribusikan kepada masyarakat dari awal merujuk pada disfungsinya mesin pompa air. Menurut Pak Mujiat selaku Ketua RW 07 (Ketua pengelola Sumber Mata Air Tirto Arum) mengungkapkan bahwasanya sumber mata air Tirto Arum ini merupakan sumber mata air yang kapasitas airnya cukup besar mencapai 8 liter/detik. Selama musim kemarau sumber air ini juga masih mengeluarkan air yang cukup banyak. Artinya air dapat 
memenuhi kebutuhan masyarakat meskipun pergantian musim.

Berdasarkan identifikasi di atas, maka kami berusaha untuk memberikan solusi dari permasalahan mitra tersebut dengan melakukan kegiatan pengabdian dengan judul "Tata Kelola Wilayah Sumber Mata Air Tirto Arum, Desa Srimulyo, Kecamatan Dampit Kabupaten Malang".

\section{Gambaran Umum Desa Srimulyo}

Desa Srimulyo merupakan salah satu desa yang terletak di Kecamatan Dampit Kabupaten Malang. Secara geografis, Desa Srimulyo berada di 41,50 km dari Ibukota Kabupaten Malang. Desa ini termasuk salah satu desa yang terluas di Kabupaten Malang yaitu dengan luas 20,66 $\mathrm{km}^{2}$ dan juga mempunyai banyak potensi alam, baik biotik maupun abiotik. Sumber daya alam biotik yang dominan diantaranya yaitu kopi, salak, dan pisang. Sedangkan sumber daya alam abiotik yang tersedia yaitu marmer. Disamping itu, Desa Srimulyo juga mempunyai bentang alam yang indah, sehingga memiliki potensi wisata namun belum dikembangkan. Hal itu dikarenakan medan yang sulit menyebabkan daerahnya sulit dijangkau (Dampit dalam Angka, 2018).

Selain itu kondisi Desa Srimulyo terkait mata air bisa dibilang juga cukup banyak sumber-sumber mata air kecil yang dimiliki perorangan. Ada sumber mata air yang cukup besar tetapi untuk wilayahnya masih ada di wilayah perkebunan masyarakat, warga sekitar sering menyebutnya dengan sumber mata air Tirto Arum, oleh karena itu pada pelaksanaan kegiatan ini mencoba untuk mengetahui lebih dalam terkait dengan status dan pengelolaan mata air tersebut.

\section{PENDEKATAN DAN METODOLOGI}

Pendekatan yang diterapkan dalam kegiatan ini mengacu kepada pendapat Syamsul dalam Kusdiyanti, at.al (2018), khususnya: 1) Pendekatan Sosio Karikatif, merupakan bentuk pendekatan yang didasari oleh sebuah anggapan bahwa klien (pengelola) adalah komunitas tidak berdaya, menderita, miskin yang tidak mampu memecahkan permasalahan sendiri. Oleh karenanya pengelola ditempatkan sebagai tempat yang akan dibantu, ditolong dan diberikan sumbangan berdasarkan nilai- nilai kemanusiaan (karikatif philantrophi) dan nilai-nilai keislaman. 2). Pendekatan Transformatif, merupakan bentuk pendekatan yang dilakukan dengan perubahan pandangan, pemikiran, sikap dan tingkah laku bersama menuju kemandirian personal. Nilai yang dikembangkan dalam pendekatan ini adalah bahwa manusia pada 
hakekatnya memiliki kemerdekaan dalam memilih jalan hidup dan menentukan masa depannya. Selain itu manusia memiliki harga diri dan potensi yang dapat dikembangkan, sehingga dapat menjadi faktor mendasar untuk merubah nasibnya. Performa kegiatan pendekatan ini pada umumnya diarahkan pada upaya-upaya pengembangan kesadaran kritis yang dapat menstimulir terjadinya transformasi nilai kehidupan.

Selain itu, dalam kegiatan pengabdian ini dipergunakan metoda Participatory Rural Appraisal (PRA). PRA adalah suatu metode pendekatan untuk mempelajari kondisi dan kehidupan pedesaan dari, dengan, dan oleh masyarakat desa. Atau dengan kata lain dapat disebut sebagai kelompok metode pendekatan yang memungkinkan masyarakat desa untuk saling berbagi, meningkatkan, dan menganalisis pengetahuan mereka tentang kondisi dan kehidupan desa, membuat rencana dan bertindak (Chambers, 1995).

Berdasarkan kepada pendekatan tersebut, kegiatan ini difokuskan pada:

1. Perbaikan mesin pompa air, dimana lumpur masuk pada filter mesin menimbulkan kerusakan pada mesin pompa.

2. Pembersihan sekitar sumber. Karena longsoran lumpur telah menimbun mesin pompa yng menyebabkan kinerja mesin menjadi lebih berat.

3. Pembenahan dinding sumber untuk menahan longsor, dimana jika musim hujan mengalami longsor karena tidak ada penahan, sehingga menutupi bak control sumber mata air.

4. Melakukan FGD dengan pemilik sumber, pengelola dan BPD untuk mendapatkan kepastian kepemilikan lahan sumber mata air Tirto Arum dan tandon.

5. Penanaman bunga sekitar tendon.

Pendekatan diatas digambarkan alurnya pada Gambar 1 sebagai berikut:

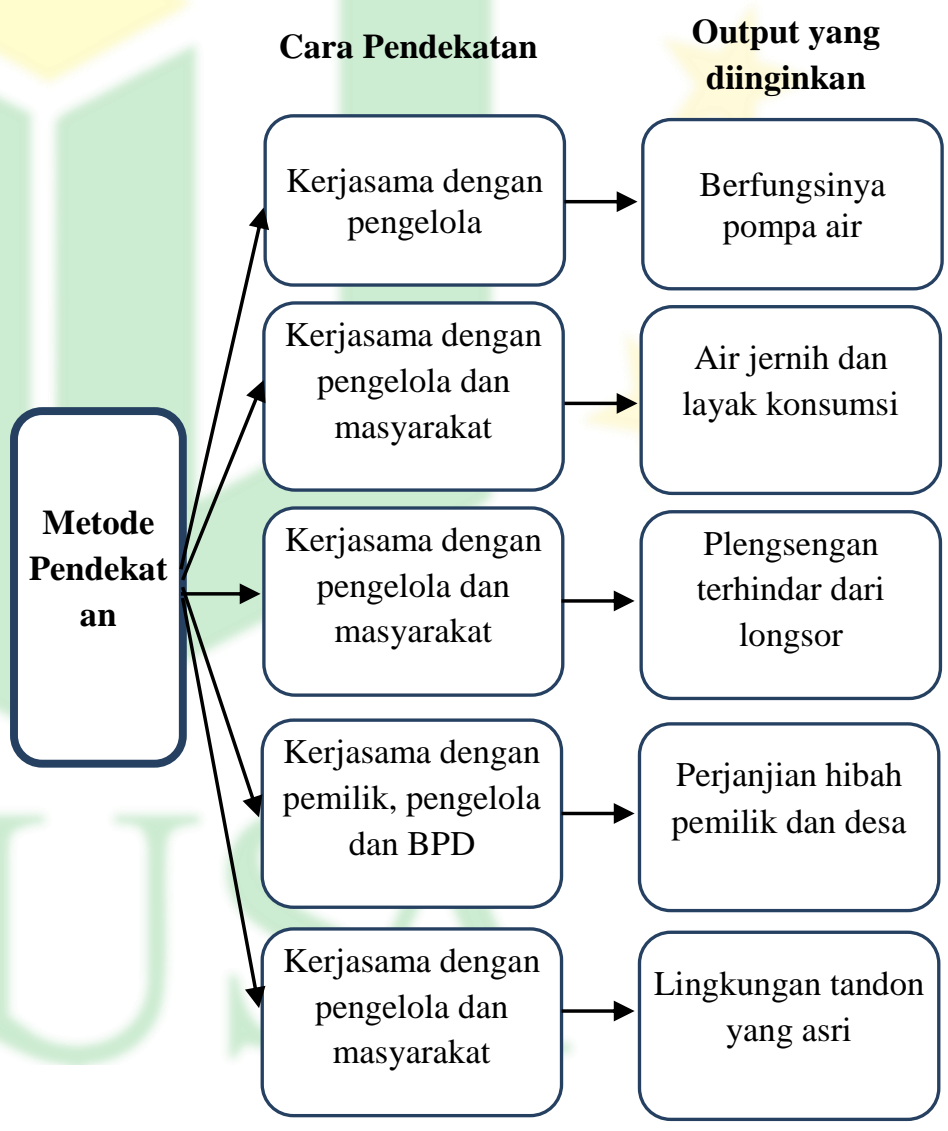

Gambar 1. Alur Pendekatan dan Output yang Diinginkan 


\section{HASIL DAN PEMBAHASAN}

Kegiatan pertama yang dilakukan adalah perbaikan mesin pompa air yang mengalami kerusakan. Mesin Pompa yang berfungsi untuk mendistribusikan air ke 196 KK di Desa Srimuyo RW 2, Kecamatan Dampit, Kabupaten Malang, pada 20 Pebruari 2019 mengalami kerusakan.

Menurut Bapak Ponijo (57) selaku ketua pengelola sumber mata air dan Ketua Gapoktan Mulyo Makmur mesin pompa yang sudah beroperasi selama satu tahun tersebut yaitu dari tahun 2018 sampai dengan 2019 mengalami kerusakan disebabkan karena mesin bekerja di luar kapasitas. Mesin pompa air berkekuatan 7,5 PK dengan kapasitas ketinggian 80 meter digunakan untuk mengaliri air dengan kapasitas ketinggian 100 meter". Sehingga diluar kapasitas kerja mesin. Karenanya, mesin bekerja terlalu keras, sehingga penghubung yang menghubungkan antara dinamo dan kipas di dalam mesin terlepas. Pantauan pada tanggal 20 Pebruari 2019, disamping memperbaiki mesin pompa yang rusak, hal yang juga perlu dilakukan adalah membersihkan longsoran lumpur.

Karena longsoran lumpur telah menimbun mesin pompa yang menyebabkan kinerja mesin menjadi lebih berat. Menurut Bapak Ponijo "tanah longsor yang menimbun mesin hampir 30 $\mathrm{cm}$ sedangkan di dalam bak penampungan air mencapai $50 \mathrm{~cm}$ ”. Lumpur masuk pada filter mesin menimbulkan kerusakan pada mesin pompa. Akibatnya air yang terdistribusi kepada masyarakat menjadi tidak jernih.

Proses perbaikan mesin memakan waktu 2 hari, yaitu dimulai dari hari Rabu, 20 Pebruari 2019 mulai pukul 07.00 WIB sampai 19.30 WIB. Hingga Kamis (21 Pebruari) pukul 18.00 WIB. Perbaikan mesin pompa melibatkan anggota pengelola sumber mata air yang berjumlah 3. Perbaikan dimulai dengan membawa mesin ke bengkel bubut AS Sedayu, Turen. Untuk dibubut dan di las. Kemudian menata mesin agar mudah di bongkar pasang.

Sedangkan tandon dikuras agar lumpur yang ada di dalam tandon terbuang dan tidak menyumbat saluran air. Pada hari Sabtu, 23 Pebruari 2019 dilakukan pemasangan pompa air. Proses pemasangan memakan waktu 6 jam dan pada jam 16.00 WIB pompa air menyala dengan normal. Pengisian tandon hingga penuh membutuhkan waktu selama lima jam. Akhirnya air dapat terdistribusikan ke masyarakat pukul 23.00 WIB. 


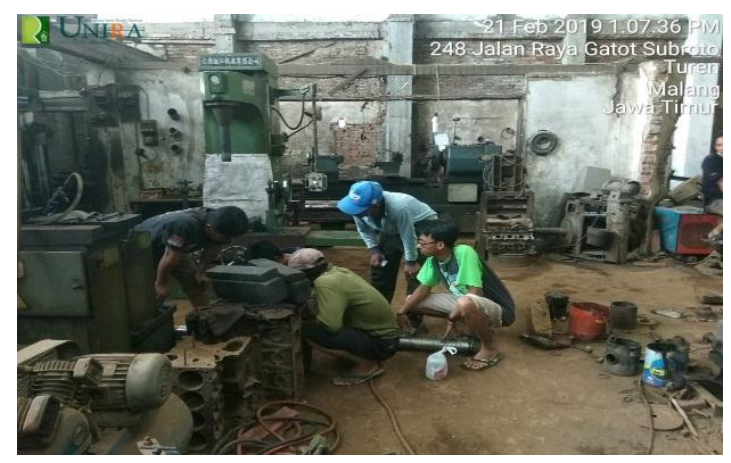

Gambar 2. Proses Pengelasan dan Perbaikan Mesin Pompa Air

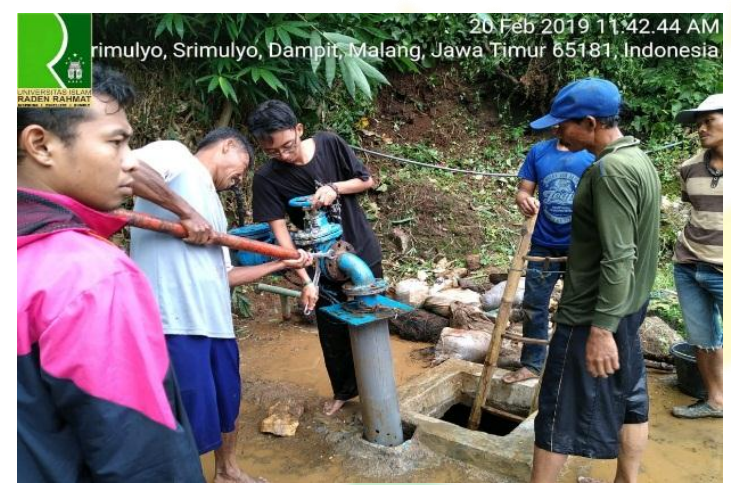

Gambar 3. Proses Pemasangan Kembali Pompa Air yang sudah Diperbaiki

Kegiatan kedua adalah pembenahan area sekitar sumber. Pembenahan dilakukan oleh masyarakat dengan bantuan beberapa mahasiswa Universitas Islam Raden Rahmat Malang selama 2 hari. Setelah mesin berfungsi dengan baik, pada tanggal 27 Februari 2018 mulailah dilaksanakan pembenahan di area sumber mata air yang tertimbun tanah longsor. Pembenahan memakan waktu yang cukup lama karena keterbatasan alat dan juga sumber daya yang ada. Untuk pembenahan disekitar wilayah sumber mata air, warga dan mahasiswa KKN-T kelompok 24 Universitas Islam Raden Rahmat Malang membuat dinding penahan longsor. Dinding dibuat dengan menggunakan karung yang diisi tanah dan ditata supaya tidak terjadi longsor yang kedua kalinya. Selain penataan pada sekitar wilayah sumber mata air, manajemen pengelolaan juga sangat perlu diperhatikan oleh para pengelola. Karena dengan manajemen pengelolaan yang baik maka akan berpengaruh pada keefisienan dan keefektifan pada pelaksanaan dan pengelolahan sumber mata air Tirto Arum.

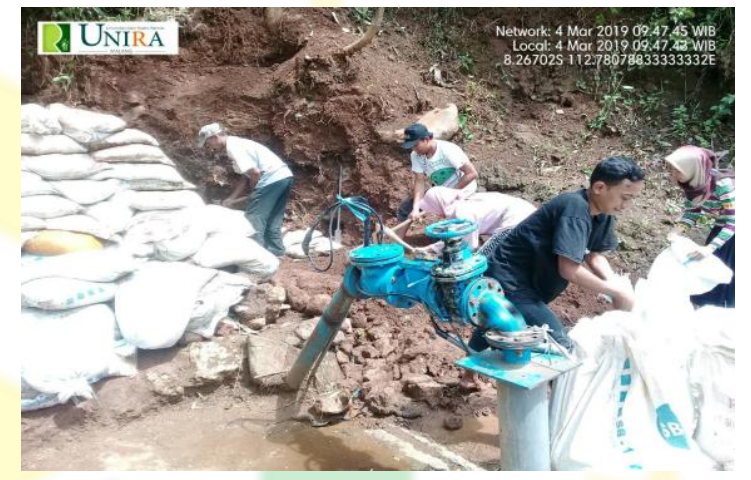

Gambar 4. Proses Pembuatan Dinding Penahan Longsor

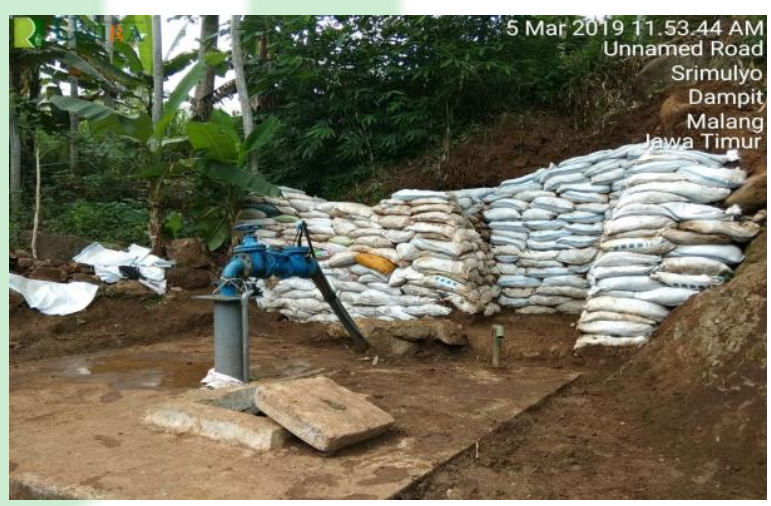

Gambar 5. Pembuatan Dinding Penahan Longsor $90 \%$

Kegiatan ketiga adalah kepastian status kepemilikan lahan sumber mata air Tirto Arum dan tandon. Sumber mata air Tirto Arum ini merupakan salah satu sumber mata air yang cukup besar. Selain fokus pada tata manajemen pengelolaannya, status wilayah tersebut juga harus diperjelas. Agar nantinya 
dalam perjalanan kedepan tidak ada permasalahan atas wilayah tersebut. Pak Wagiman selaku pemilik tanah di wilayah sumber mengungkapkan memang tidak ada kejelasan atau perjanjian hitam diatas putih antara Pak Wagiman dengan pihak desa yang diwakili oleh Pak Wajib. Setelah itu Pak Wajib meninggal dan tidak ada kelanjutan terkait pembahasan wilayah tersebut. Hal ini bukan saja terjadi pada Pak Wagiman (pemilik tanah pada sumber mata air) tetapi juga pada Pak Mul (pemilik tanah pada tandon air). Bapak Wagiman dan Bapak Mul maupun pihak desa tidak memiliki surat perjanjian yang sah atau kesepakatan bersama, karena semua pihak belum pernah duduk bersama menyelesaikan masalah itu.

Berbekal pengamatan dan diskusi secara personal dengan pihak-pihak yang berkaitan dengan sumber mata air Tirto Arum, maka pada tanggal 14 Maret 2019 kami menginisiasi kegiatan rembuk pengelolaan sumber mata air Tirto Arum yang dihadiri oleh pemerintah desa, pengelola dan juga Bapak Wagiman selaku pemilik tanah di sumber dan Bapak Mul sebagai pemilik lahan di tandon. Kegiatan bertempat di salah satu rumah warga yaitu ibu Suginem/ibu Neneng.

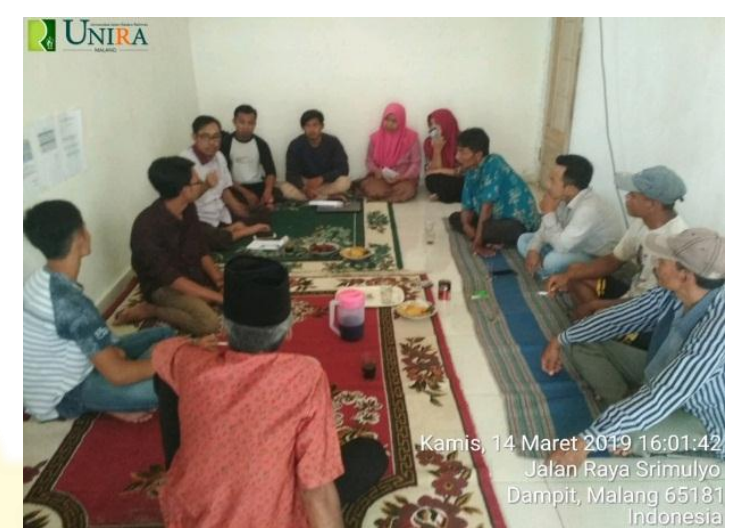

Gambar 6. Proses Rembuk Kepemilikan Sumber Air Tirto Arum dan Lahan di Tandon Air

Dari rembuk tersebut dihasilkan beberapa hal terutama yang paling penting adalah bahwa Bapak Wagiman sebagai pemilik lahan di sumber mata air Tirto Arum dan Bapak Mul sebagai pemilik di lahan tandon secara ikhlas menyerahkan lahan mereka kepada Desa Srimulyo untuk dikelola. Hasil rembuk tersebut ditindaklanjuti dengan ditandatangani surat perjanjian hibah di atas materai antara Pemerintah Desa Srimulyo dengan Bapak Wagiman dan Bapak Mul.

Hasil dari rembuk pengelola sumber mata air, diantaranya:

1. Semua pihak yang hadir sepakat bahwa desa (BUMDES), pengelola dan pemilik lahan harus mendapatkan manfaat dan keuntungan dari pengelolaan sumber mata air Tirto Arum.

2. Bapak Wagiman selaku pemilik lahan sumber mata air dengan ikhlas menghibahkan sumber mata air ke desa 
yang akan ditindaklanjuti dengan surat perjanjian.

3. Disepakati bahwa harus ada pembagian presentase dari pendapatan bersih bulanan.

4. Dengan adanya kesepakatan ini akan secepatnya dibuatkan perjanjian secara tertulis di atas materai antara Bapak Wagiman (selaku pemilik sumber mata air) dengan pihak desa berkenaan dengan hibah sumber mata air Tirto Arum.

5. Dalam rangka pengelolaan sumber mata air dan beberapa kegiatan di Desa Srimulyo dibutuhkan pendampingan dari Universitas Islam Raden Rahmat (Unira) Malang untuk transfer ilmu.

6. Secepatnya diadakan pembicaraan lebih lanjut dengan pemilik lahan di tandon utama (Pak Mul) untuk memperjelas status kepemilikan lahan. Sebagai informasi bahwa pada awal pembangunan tandon utama sumber mata air Tirto Arum juga dihibahkan kepada desa oleh pemilik lahan.

7. Berita acara ini dan perjanjian pak Wagiman dengan pihak desa, perjanjian pemilik lahan tandon utama (Pak Mul) menjadi dasar pembuatan PERDES tentang pengelolaan sumber mata air Tirto Arum Desa Srimulyo.

Hasil rembuk tersebut disepakati oleh semua pihak dan akan ditindaklanjuti oleh desa yang akan didampingi oleh
Dosen dan beberapa mahasiswa Universitas Islam Raden Rahmat (UNIRA) Malang. Selanjutnya bila masalah status wilayah sudah selesai maka akan dibentuknya BUMDES (Badan Usaha Milik Desa) sebagai wadah dari sumber mata air dan semua potensi-potensi yang ada di Desa Srimulyo.

Di akhir pelaksanaan program mengenai tata kelola sumber mata air Tirto Arum Desa Srimulyo, maka dilakukan penanaman bunga di daerah sekitar tandon air. Tujuan dengan kegiatan ini adalah agar daerah sumber mata air bersih dan terawat. Selain itu, daerah yang asri dan sejuk agar tetap menjadi notabene Desa Srimulyo yang belum tercemar limbah.

Tata Kelola Wilayah Sumber Mata Air Tirto Arum Desa Srimulyo dilaksanakan selama 15 hari. Mulai dari perbaikan mesin pompa air, pembersihan sekitar sumber, pembenahan dinding sumber untuk menahan longsor, kepastian kepemilikan lahan sumber mata air Tirto Arum dan tandon, dan penanaman bunga sekitar tandon. Beberapa hal yang dihasilkan adalah:

1. Berfungsinya kembali mesin pompa air untuk mengalirkan air dari sumber air Tirto Arum ke tandon yang selanjutnya didistribusikan ke warga.

2. Tertatanya lingkungan sumber air Tirto Arum dengan cara dibersihkan 
longsoran dan membuat dinding penahan longsor dengan menggunakan karung yang diisi tanah dan pasir.

3. Sumber air Tirto Arum resmi menjadi milik Desa Srimulyo dengan telah ditanda tanganinya perjanjian hibah secara tertulis di atas materai antara pemilik sumber air (Bapak Wagiman) dengan Desa Srimulyo (diwakili Kepala Desa).

4. Tanah yang ditempati tandon air juga menjadi milik Desa Srimulyo dengan telah ditandatanganinya perjanjian hibah secara tertulis di atas materai antara pemilik tanah tempat tandon (Bapak Mul) dengan Desa Srimulyo (diwakili Kepala Desa).

5. Ditanda tanganinya MoU antara Unira Malang (diwakili oleh Ketua LPPM) dan Pemerintah Desa Srimulyo (diwakili Kepala Desa) sebagai langkah awal untuk pelaksanaan Tridharma Perguruan Tinggi di Desa Srimulyo.

\section{KESIMPULAN}

1. Tata kelola sumber mata air Tirto Arum di Desa Srimulyo melalui beberapa tahapan, yaitu:

a. Perbaikan pompa air.

b. Pembersihan daerah sekitar sumber mata air dan tandon air.

c. Pembuatan dinding penahan longsor. d. Legalisasi kepemilikan lahan sumber mata air dan tandon.

e. Penanaman bunga di sekitar daerah tandon.

2. Untuk pendampingan lebih lanjut telah dibuat MoU antara Unira Malang yang diwakili oleh Ketua LPPM dengan Desa Srimulyo, yang salah satunya adalah pendampingan pembuatan Peraturan Desa tentang pengelolaan sumber mata air Tirto Arum, begitu juga dengan hal yang berkaitan dengan tata kelola sumber mata air itu sendiri.

\section{SARAN}

Saran yang dapat kami berikan untuk keberlanjutan kegiatan dan kegiatan lainnya yang bersinggungan adalah sebagai berikut:

1. Pemerintah Desa Srimulyo seyogyanya berperan aktif dalam pembuatan kerjasama dengan pihak lain, khususnya perguruan tinggi, untuk melakukan pendampingan dalam rangka memajukan desa dan ikut serta dalam mensejahterakan masyarakatnya.

2. Badan Usaha Milik Desa (BUMDES) di Desa Srimulyo segera direalisasikan dengan cara melegalisasi keberadaannya agar pengelolaan sumber mata Air Tirto Arum dan usaha-usaha lain yang ada di desa segera mempunyai wadah formal. Selain itu, BUMDES 
merupakan amanat Undang-undang Desa Nomor 6 Tahun 2014.

3. Kepada pengelola sumber air Tirto Arum segera melakukan inventarisasi kembali berkaitan dengan biaya-biaya yang harus dikeluarkan konsumen mulai dari biaya pemasangan dan biaya-biaya lainnya serta sesegera mungkin di sosialisasikan kepada konsumen agar kecurigaan konsumen yang selama ini ada dapat diminimalisir.

\section{UCAPAN TERIMA KASIH}

Pada kegiatan ini saya banyak mendapat dukungan dari barbagai pihak dan dalam kesempatan ini saya menyampaikan ucapan terimakasih kepada :

1. LPPM Unira Malang yang telah memfasilitasi kegiatan pengabdian kepada masyarakat ini.

2. Kepala Desa Srimulyo yang telah memberikan ijin untuk pelaksanaan kegiatan pengabdian.

3. Sekretaris Desa, Ketua BPD dan pengelola sumber mata air Tirto Arum Desa Srimulyo atas keramahan dan informasi serta berbagai fasilitas yang diberikan kepada kami.

4. Mahasiswa kelompok $24 \mathrm{KKN}-\mathrm{T}$ Unira Malang tahun 2019, terima kasih atas semua keramahan dan kerjasamanya.

\section{DAFTAR PUSTAKA}

Badan Pusat Statistik Kabupaten Malang. 2018. Kecamatan Dampit dalam Angka. Malang: Kurnia Offshet

Chambers, R. 1996. Participatory Rural Appraisal: Memahami Desa Secara Partisipatif. Oxfam-Kanisius. Yogyakarta

Kodoatie, Robert J dan Rustaman Syarf. Pengelolaan Sumber Daya Air Terpadu. 2005. Yogyakarta: ANDI

Kusdiyanti, Heny. M. Nurruddin Zanky, Lifa Farida P, dan Andy Prasetyo Wati. 2018. Program Pengem bangan Kewirausahaan Petani Selada Air Poncokusumo. Jurnal At Tamkin, Volume 1 omor 1, Mei 2018. Hal $45-55$.

Rasyid, Nassa Ruddin. 2018. Dampit Dalam Angka 2018. Malang: BPS Kabupaten Malang

2019. Mata Air. https://id.wikipedia.org/wiki/Mata_ air. Diakses pada tanggal 6 maret 2019, pukul 11.24 WIB. 